\title{
A review of the pathogenicity mechanism of Verticillium dahliae in cotton
}

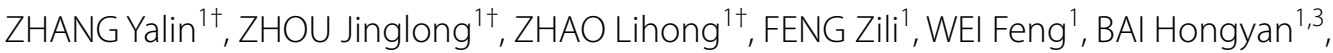 \\ FENG Hongjie ${ }^{1,2^{*}}$ (D) and ZHU Heqin ${ }^{1 *}$
}

\begin{abstract}
Verticillium wilt, caused by the notorious fungal pathogen Verticillium dahliae, is one of the main limiting factors for cotton production. Due to the stable dormant structure microsclerotia, long-term variability and co-evolution with host plant, its pathogenicity mechanism is very complicated, and the interaction mechanism between pathogen and host plant is also unclear. So identification and functional analysis of the genes involved in the pathogenicity or virulence of this fungus will benefit to uncover the molecular pathogenic mechanism of $\mathrm{V}$. dahliae. In this review, many multifunction genes covering microsclerotia development, pathogen infection, effector proteins, transcription factors, horizontal gene transfer and trans-kingdom RNA silencing have been summarized to provide a theoretical basis to deep understand the molecular pathogenicity mechanism of $V$. dahliae and promote to effectively control Verticillium wilt. Furtherly, these pathogenicity-related genes may be considered as targets for effective control of Verticillium wilt in cotton.
\end{abstract}

Keywords: Verticillium dahliae, Cotton, Pathogenicity-related genes, Molecular pathogenic mechanism

\section{Background}

Verticillium dahliae Kleb. is a soil-borne hemibiotrophic phytopathogenic fungus with a wide host range and worldwide distribution, which generally causes plant dysplasia, leaf wilting and yellowing, vascular bundles browning, and eventually leading to early death (Klosterman et al. 2009; Zhou et al. 2021). Because of stable dormant structure microsclerotia, this fungus can survive in the soil for more than ten years even under adversity conditions (Fradin and Thomma 2006). Moreover, the pathogen population is rich in genetic diversity and its pathogenicity is prone to variability. In the field, it coevolves with host plant to appear a strong pathotype (Atallah et al. 2010; Song et al. 2020). Many researches

\footnotetext{
*Correspondence: fenghongjie@caas.cn; heqinanyang@163.com ${ }^{\dagger}$ Zhang YL, Zhou JL and Zhao LH contributed equally to this work ${ }^{1}$ State Key Laboratory of Cotton Biology, Institute of Cotton Research of Chinese Academy of Agricultural Sciences, Anyang 455000, Henan, China

Full list of author information is available at the end of the article
}

have been made to control Verticillium wilt, such as breeding resistant cultivars, crop rotation, developing soil fumigants, applying chemical fungicides, as well as biological control (Acharya et al. 2020; Ingram et al. 2020; Zhang et al. 2021). Unfortunately, Verticillium wilt still results in extensive economic losses.

Cotton, a primary natural fiber producing crop of great importance to the global textile industry, suffers from tremendous yield losses in $V$. dahliae-infested soil approximately $10 \%$ 35\% in many countries annually, and the fiber quality by reducing micronaire and span length, which is considered as the cancer of cotton production (Fradin and Thomma 2006; Zhang et al. 2011). The objective of this review is to summarize the molecular pathogenicity mechanism of $V$. dahliae, with major focus on the cotton- $V$. dahliae complicated interaction, and provide a theoretical basis for further effective control of cotton Verticillium wilt.

The plant immunity system has been described as a 'zigzag' model, which exhibits a systematic explanation original author(s) and the source, provide a link to the Creative Commons licence, and indicate if changes were made. The images or other third party material in this article are included in the article's Creative Commons licence, unless indicated otherwise in a credit line to the material. If material is not included in the article's Creative Commons licence and your intended use is not permitted by statutory regulation or exceeds the permitted use, you will need to obtain permission directly from the copyright holder. To view a copy of this licence, visit http://creativecommons.org/licenses/by/4.0/. 
of the dynamic balance between pathogen and host plant in the arms race between pathogenicity and disease resistance (Jones and Dangl 2006). Plants recognize pathogen-associated molecular patterns (PAMPs) through pattern recognition receptors (PRRs) to trigger immunity responses (PAMPs-triggered immunity, PTI); Plants use $\mathrm{R}$ proteins to specifically discern pathogen effectors, thereby activating further complex immunity responses (Effector-triggered immunity, ETI). In order to avoid or suppress plant immune responses, pathogens have evolved more diverse effector proteins to successfully infect plants. As a PAMPs, the xyloglucan hydrolase PsXEG1 secreted by Phytophthora sojae plays a virulence factor to help pathogen infection. Meanwhile, soybean can distinguish PsXEG1 to trigger immune reactions, leading to inhibit the infection of $P$. sojae. However, the RXLR effector proteins are recruited by $P$. sojae to suppress these immune responses and successfully infect soybean (Ma et al. 2015). Further study has been shown that PsXEG1 and PsXLP1, which contain conserved domains, coordinately regulate pathogen infection in soybean. PsXLP1 competitively interferes with the suppressor GmGIP1 as a bait, thereby saving PsXEG1 and leading to disease occur ( $\mathrm{Ma}$ et al. 2017). So far, this new pathogenic mechanism has yet not been found in cotton- $V$. dahliae battle. As a well-known PAMPs, chitin is unique among the major component of fungal cell walls, triggering host immunity and restraining pathogen infection. De Jonge et al. (2010) demonstrated that lysine motif (LysM) domain-containing effector protein Ecp6 of Cladosporium fulvum mediated pathogenicity by blocking the chitin-triggered host immunity, which represents a common strategy of host immune suppression. Interestingly, Gao et al. (2019) revealed that deacetylation of chitin avoided host perception by LysM-containing receptor as a major virulence strategy, due to the reason that PDA1 possesses deacetylation activity and pathogenicity traits in both $V$. dahliae and Fusarium oxysporum, with conserved domains in Ascomycota. All these evidences showed that deacetylation of chitin to elude host perception is a conserved and common intercellular stealth tactic of soil-borne pathogenic fungi.

The molecular pathogenicity mechanism of $V$. dahliae is very complex, which is related to a large number of pathogenicity-related genes. In recent years, researchers have studied $V$. dahliae pathogenicity-related genes through various perspectives such as genome, transcriptome, proteome and T-DNA mutant library, having made phased progress (Gold et al. 2017; Qi et al. 2015; Rehman et al. 2016; Wu et al. 2019). Functional analysis of these multifunctional genes involved in the fungus growth and pathogenicity is the molecular genetic basis of revealing pathogenesis of $V$. dahliae. Up to now, genes related to growth and development are not necessarily correlated to pathogenicity, on the contrary, genes related to pathogenicity more or less connected with vegetative growth (Luo et al. 2014). Unfortunately, the pathogenicity- or virulence-related genes in wilt fungus, which may be as potential targets for controling plant Verticillium wilt disease, remaining poorly elucidated. In this review, some key findings and pathogenicity-related genes are summarized to provide a theoretical basis for further understanding of the molecular pathogenicity mechanism of $V$. dahliae.

\section{Biological processes in pathogenicity of $V$. dahliae Microsclerotia development}

As the long-term survival resting structure, microsclerotia plays a critical role in the disease cycle as primary sources of infection, germination of microsclerotia is the first step in host invasion and initiation of Verticillium wilt disease (Fradin and Thomma 2006; Shaban et al. 2018; Zhang et al. 2016c) (Fig. 1). Although microsclerotia development is not always correlated with virulence, some studies have uncovered evidences that the decrease in microsclerotia and melanin reduce pathogenicity and survival of $V$. dahliae isolates (Rauyaree et al. 2005; Tzima et al. 2010; Zhang et al. 2015). However, VdPKAC1 (cAMP-dependent protein kinase A), VGB (G protein $\beta$ subunit gene), $V d M s n 2\left(\mathrm{C}_{2} \mathrm{H}_{2}\right.$ transcription factor $)$ and VdPLP (patatin-like phospholipase gene) negatively regulated the formation of microsclerotia, and the deletion mutants of those genes caused lower fungal pathogenicity with higher production of microsclerotia (Qi et al. 2018; Tian et al. 2017; Tzima et al. 2012). A total of 1 654 genes with differential expression have been identified by analyzing whole genome-wide expression profiles of germinating microsclerotia in $V$. dahliae $(\mathrm{Hu}$ et al. 2014). This process was more likely to regulate by transcription factors including $\mathrm{C}_{2} \mathrm{H}_{2}$, bZIP and fungal-specific transcription factors domain-containing proteins. In addition, G-protein receptors, $\mathrm{Ca}^{2+}$, small GTPases, and cAMP were involved in this signal transduction (Luo et al. 2019).

Generally, microsclerotia and melanin appear together, thus most genes coordinately regulate the development of microsclerotia and the accumulation of melanin ( $\mathrm{Li}$ et al. 2019a). Vayg1 (dihydroxynaphthalene (DHN)-melanin), the common form among fungi and named for the intermediary of melanin biosynthetic pathway, is necessary for melanin and microsclerotia production (Fan et al. 2017). VdSsk1 (response regulator), transcription factor VdCmr1, cluster-specific genes VdPKS1 (polyketide synthase), and VdLac1 (laccase) encoding at initial and endpoint steps in DHN melanin production, were required for melanin synthesis, but neither required for 


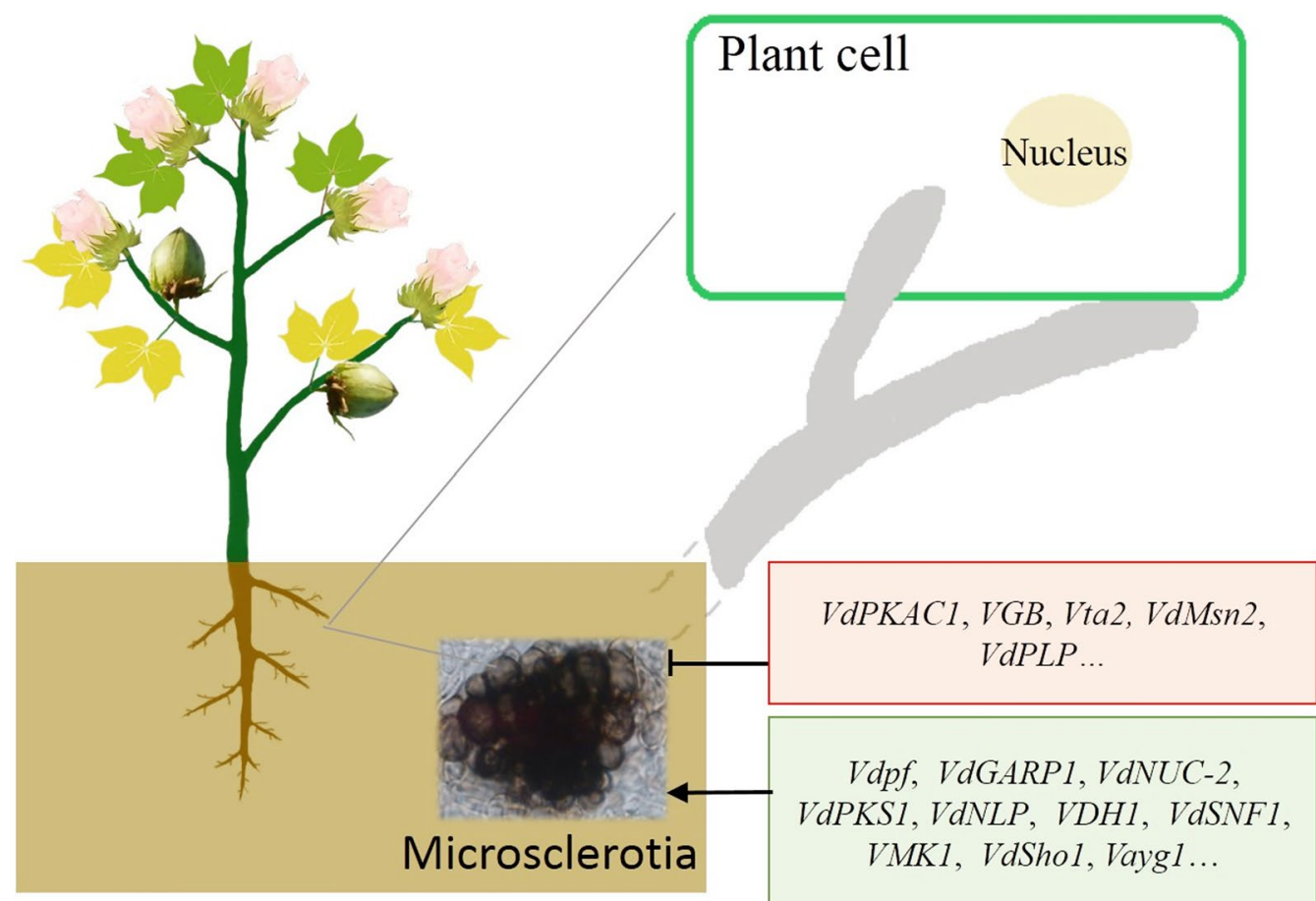

Fig. 1 The simple schematic diagram of the infection process of Verticillium dahliae in cotton. As the initial source of infection, microsclerotia survives in the soil for a long time. Once the conditions are suitable, the microsclerotia germinates to form hyphae and infects cotton root tips. Some postive/negative regulation genes are involved in microsclerotia development

microsclerotia formation (Fang et al. 2019; Wang et al. 2018c; Zheng et al. 2019). Additionally, the high osmolarity glycerol (HOG) pathway is an important regulatory strategy for microsclerotia and melanin synthesis. VdHog1, a mitogen-activated protein kinase, controled microsclerotia formation, virulence and stress reaction of $V$. dahliae. VdPbs2, the conserved upstream component of VdHog1, was a key regulator of microsclerotia formation (Tian et al. 2016; Wang et al. 2016a, b). And VdMsn2 was predicted to function as a downstream player in the HOG pathway, disruption mutants produced significantly higher microsclerotia (Tian et al. 2017). Furthermore, RNA-Seq used to analyze the response of $V$. dahliae to nutrient starvation indicated that melanin biosynthesis and microsclerotia development were induced under nitrogen starvation, but microsclerotia development was suppressed under carbon starvation (Xiong et al. 2015).

\section{Systemic infection}

The initial interaction of a pathogenic fungus with host is complex and involves numerous metabolic pathways. Verticillium wilt is a typical systemic vascular infection disease, successful adhesion and penetration of host plant root are the first step for V. dahliae to systematically infect and cause disease (Du et al. 2017). During colonization, $V$. dahliae spores develop into hyphae surrounding the roots. Only a few hyphae tightly adhere to the root surface and form hyphopodium at the infection site, which further growth into penetration pegs to facilitate infection. Unlike the infestation nail of Magnaporthe grisea, Verticillium species lack this special structure, and their attachment depends on some molecules, such as hyphopodium and adhesins (Eynck et al. 2007). Vta1 (transcription activator of adhesion 1) rescued adhesion in non-adhesive Saccharomyces cerevisiae cells, Vta2 and $V t a 3$ were required for early steps in plant colonization and infection (Tran et al. 2014). However, Harting et al. (2020) revealed that Vta1 function was dispensable for root colonization and infection, but required for melanin production and activated transcription of melanin biosynthesis genes including the polyketide synthase encoding PKS1 and the laccase LAC1. VdSho1 (tetraspan transmembrane protein), as an osmosensor, was necessary for plant penetration and melanin synthesis contributing to virulence ( $\mathrm{Li}$ et al. 2019a). Besides, two transcription factors Vph1 (VDAG_06555) and Vhb1 (VDAG_08786) were also participated in penetration (Sarmiento-Villamil et al. 2018b). Msb encoded a transmembrane mucin with highly conservative in the Mitogen-activated protein kinase (MAPK) signal pathway, the 
invasive growth and adhesive capacity of $V d M s b$ deletion mutants were significantly decreasing (Tian et al. 2014). VdPls1 (tetraspanin) and VdNoxB (catalytic subunit of membrane-bound NADPH (nicotinamide adenine dinucleotide phosphate) oxidase) colocated in the plasma membrane at the base of hyphopodium were specific expression in hyphopodium, indicating that NADPH oxidase regulated septin ring organization (Zhao et al. 2016). As a regulator of hyphopodium formation and pathogenicity, VdCSIN1 (cellophane surface-induced gene) regulated hyphopodium formation via cAMP-mediated signal pathway to promote host colonization of $V$. dahliae (Sun et al. 2019). After hyphopodium infected cotton root, hyphal neck was an important site for directly/indirectly pathogenic related genes during plant root infection. A septin ring, requiring VdSep5, partitioned the hyphopodium, the invasive hyphae and further formed the specialized fungi-host interface. Moreover, VdSec22, $V d S y n 8$, and VdExo70 (exocyst subunit) also inhibited transmission of the secreted proteins inside the hyphopodium and regulated virulence (Zhou et al. 2017b).

As the first physical barrier of plants, the plant cell wall plays a basic role in preventing the invasion of pathogenic fungi. If pathogens successfully infect plants, they have to break through this barrier. Analysis of the genome sequence of $V$. dahliae demonstrated that it contained a large number of genes encoding carbohydrate-activeenzymes and cell wall degrading enzymes (CWDE), which may be one of the reasons why that fungus could colonize lots of host plants. The typical secretion of CWDE include pectinases, xylanases, cellulases, and proteases (Chen et al. 2016). Pectin as the main element of the primary plant cell wall plays a key role in defence mechanism against plant pathogens. The pectate lyase (VdPEL1) induced cell death in several plants and triggered defense responses depending on enzymatic activity (Yang et al. 2018). VdSNF1 (Sucrose non-fermenting protein kinase) regulated the activity of pectinase and galactase, the pathogenicity of knockout mutants was significantly reduced during infection in tomato (Tzima et al. 2011). Besides, VdSSP1, encoding a secreted protein, has also been implicated in virulence of $V$. dahliae in cotton. VdSSP1 was essential for cell wall degradation and the absence of this gene significantly mitigated virulence (Liu et al. 2013). In addition, pathogenesis related genes VdPR1 and VdPR3 affected the infectivity via regulating the activity of cellulase (Zhang et al. 2015, 2016c). The MADS-box transcription factor $V d M c m 1$ was a key regulator of cell wall integrity (Xiong et al. 2016).

When $V$. dahliae arrives the xylem from the intercellular space of the plant root cortex, the fungus has to adapt to the intracellular environment of host plant, where only a little amount of nutrients can be obtained, with limited amino acids and vitamins. VdThit (thiamine transporter protein gene) participated in nutrient acquisition, the growth and conidiation, the impaired virulence of the $\mathrm{Vd} \Delta$ Thit mutants were partially restored by supplementing exogenous thiamine (Qi et al. 2016). Besides, VdTHI2O was involved in the thiamine biosynthesis pathway, the deletion of VdTHI2O resulted in several phenotypic defects including vegetative growth, conidiation, and virulence. Futhermore, VdTHI2O increased the tolerance of $V$. dahliae to UV damage (Qin et al. 2020). Another thiamine biosynthesis member, VdThi4 (thiazole biosynthesis protein) had putative NAD binding site, was highly conserved among Verticillium, and maintained mitochon-drial genome stability. Although the $\triangle V d T H I 4$ mutant could colonize the plant roots, it did not form a systemic infection and lose pathogenicity to tomato (Hoppenau et al. 2014). In the battle aganist plants, pathogens need to obtain iron and other micronutrients from plant cells, ferric reductases are integral membrane proteins involved in the reduction of environmental ferric iron into the biologically available ferrous iron. FreB deletion strain exhibited significantly lower growth and spore production especially on media without iron, with highly sensitive to oxidative stress (Rehman et al. 2018). The bZip transcription factor VdHapX acted as a key regulator of iron homeostasis for adaptation to iron-depleted and iron-excess conditions and was required for full virulence (Wang et al. 2018b). Once adaptes to the intracellular environment, pathogenic fungus propagates quickly and invades the vascular bundles, further blocks the vascular bundle and causes a systemic infection disease.

\section{Protein properties related to virulence of $\boldsymbol{V}$. dahliae Effector proteins}

Successful host infection requires secretion of effector proteins to evade or suppress plant immunity, effector proteins play an important role in the host infection process of pathogens and become a research hotspot (Feng et al. 2018; Stergiopoulos and de Wit 2009; Wang et al. 2020a). Most of the effector proteins have conservative sequences at the $\mathrm{N}$-terminus or $\mathrm{C}$-terminus, such as RXLR, CRN, CFEM, RGD, DELD, RYWT or Y/F/WXC, etc. (Gómez-Gómez and Boller 2000; Du et al. 2017; Liu et al. 2019; Shamraĭ 2014). Effector proteins including VdNEP, PevD1, VdCP1 were secreted by $V$. dahliae into host, all of those can induce cotton cell death and trigger immunity responses (Gui et al. 2017; Wang et al. 2004, 2012). Chen et al. (2016) used isobaric tags for relative and absolute quantitation (iTRAQ) technology to systematically analyze the secreted proteins of $V$. dahliae induced by cotton, 271 secreted proteins were found to be induced to express, of which 172 proteins had signal peptide sequences. Whole-genome sequencing and 
proteomics screen have been used to identify many of those proteins, including cysteine-rich proteins, necrosisinducing proteins and enzymes (De Sain and Rep 2015). Endochitinase $V D E C H$ was recognized by plant to elicit defense response and also was an effective inhibitor of conidia germination (Cheng et al. 2017). Secreted small cysteine-rich proteins (SCPs) play a critical role in modulating host immunity in plant-pathogen interactions. Bioinformatic analysis was showed that the fungal pathogen $V$. dahliae encoded more than 100 VdSCPs, VdSCP27, $V d S C P 113$, and VdSCP126 vitro-expressed in tobacco leaves, resulting in cell death accompanied with reactive oxygen species (ROS) burst and callose deposition. $B A K 1$ and SOBIR1 (associated with receptor-like protein) were required for host immunity triggered by those three VdSCPs (Wang et al. 2020a). In addition, expression of the VdSCP7 (small cysteine containing protein) gene in $N$. benthamiana activated both salicylic acid and jasmonate signal pathway, and altered plants' susceptibility to the pathogens Botrytis cinerea and Phytophthora capsici (Zhang et al. 2017a). As a well-researched star, PevD1 with $\mathrm{C} 2$ domain structure and $\mathrm{C}$-terminal acidic pocket activated a hypersensitive responses such as necrosis and systemic acquired resistance in many plants including cotton, tobacco and Arabidopsis (Liang et al. 2018; Zhang et al. 2019b; Zhou et al. 2017a). In cotton, $V$. dahliae secreted PevD1 to inhibit GhPR5 (a partner protein of PevD1) antifungal activity in order to overcome host defence system. As a PAMPs, glycoside hydrolase 12 (GH12) proteins widely present in oomycetes and filamentous fungi. Gui et al. (2017) revealed that VdEG1 and $V d E G 3$ (two of GH12 proteins) acted as PAMPs to trigger host cell death. VdEG1 and VdEG3 associated with BAK1 and SOBIR1 to initiate host immunity, respectively. However, they both binded with CBM1-containing proteins to manipulate plant immunity.

\section{Transcription factors}

Bioinformatic analysis proved that $V$. dahliae coded approximately 530 transcription factors divided into 42 families. Jin et al. (2019) clarified that transcription factors contained fungi specific conservative domain and fungal Zn2-Cys6 binuclear cluster domain were abundance in V991w, which was an attenuated virulence strain of $V$. dahliae. Increasing evidences have been revealed that transcription factors play an important role in the interaction between pathogen and host plant (Depotter et al. 2019; Shaban et al. 2018). Vdpf, a fungal-specific transcription factor-encoding gene, was associated with vegetative growth and virulence. $\Delta V d p f$ mutants were melanin deficient, with undetectable expression of melanin biosynthesis-related genes Brn1, Brn2, and $S c d 1$ (Luo et al. 2016). Sarmiento-Villamil et al. (2018a, b) characterized the APSES family transcription factor Vst1 in $V$. dahliae and $V$. nonalfalfae, the absence of $V s t 1$ had a great impact on sporulation, especially affected sporulation rates in liquid medium. However, Vst1 was dispensable for virulence. Fungal transcription factors (TFs), the VdFTF1-deletion strains exhibited significantly reduced virulence in cotton, but with normal vegetative growth, mycelial pigmentation, and conidial morphology (Zhang et al. 2018). In addition, nuclear transcription factors Som1 and Vta3 were prerequisite for root penetration and host plant colonization (Bui et al. 2019). bZIP transcription factors are ubiquitous in animals, plants, and microorganisms, acting various biological roles in stress responses, conidiation, and pathogenicity in pathogenic fungi. Homolog of the bZIP transcription factor Atf1, $V d A t f 1$ controled pathogenesis via the regulation of nitric oxide resistance and inorganic nitrogen metabolism rather than oxidative resistance, responding to nitrosative stress and nitrogen metabolism in $V$. dahliae (Tang et al. 2020). Two bZIP transcription factors (VDAG_08640 and VDAG_08676) disrupt mutants showed remarkably higher sensitivity to hydrogen peroxide stress (Fang et al. 2017). Besides, disruption of VdHapX (bZip transcription factor) led to decreased formation of the long-lived survival structure (Wang et al. 2018b). V. dahliae deployed an effector protein VdSCP41 into plants to disrupt the functions of SARD1 and CBP60g, two central transcriptional regulators of plant immunity (Ding and Redkar 2018).

\section{Genetic mechanism in pathogen-plant interaction Horizontal gene transfer}

Horizontal gene transfer (HGT) refers to the transmission of genetic material between individual organisms, internal organelles of a single cell and even distinct evolutionary lineages, which is an important source of biological innovation and a common case in the interaction between host plant and pathogen (Cai et al. 2018; Daboussi and Capy 2003). The effector gene Ave1 and a glucosyltransferase-encoding gene $V d G T 2$ were identified as pathogenicity genes which were proposed to be horizontally acquired from a plant and a bacterial donor, respectively (Shi-Kunne et al. 2019). However, the direct experimental evidences of the transferred genetic material from another related or unrelated fungal species were insufficient (Depotter et al. 2019; Mehrabi et al. 2011). Klosterman et al. (2011) have sequenced the genomes of $V$. dahliae and $V$. albo-atrum, compared with the genome of $F$. oxysporum, a set of proteins were shared among all three wilt pathogens. In addition, the high level of synteny between the two Verticillium assemblied highlighted four flexible genomic islands in V. dahliae, with enriched transposable elements and contained duplicated genes 


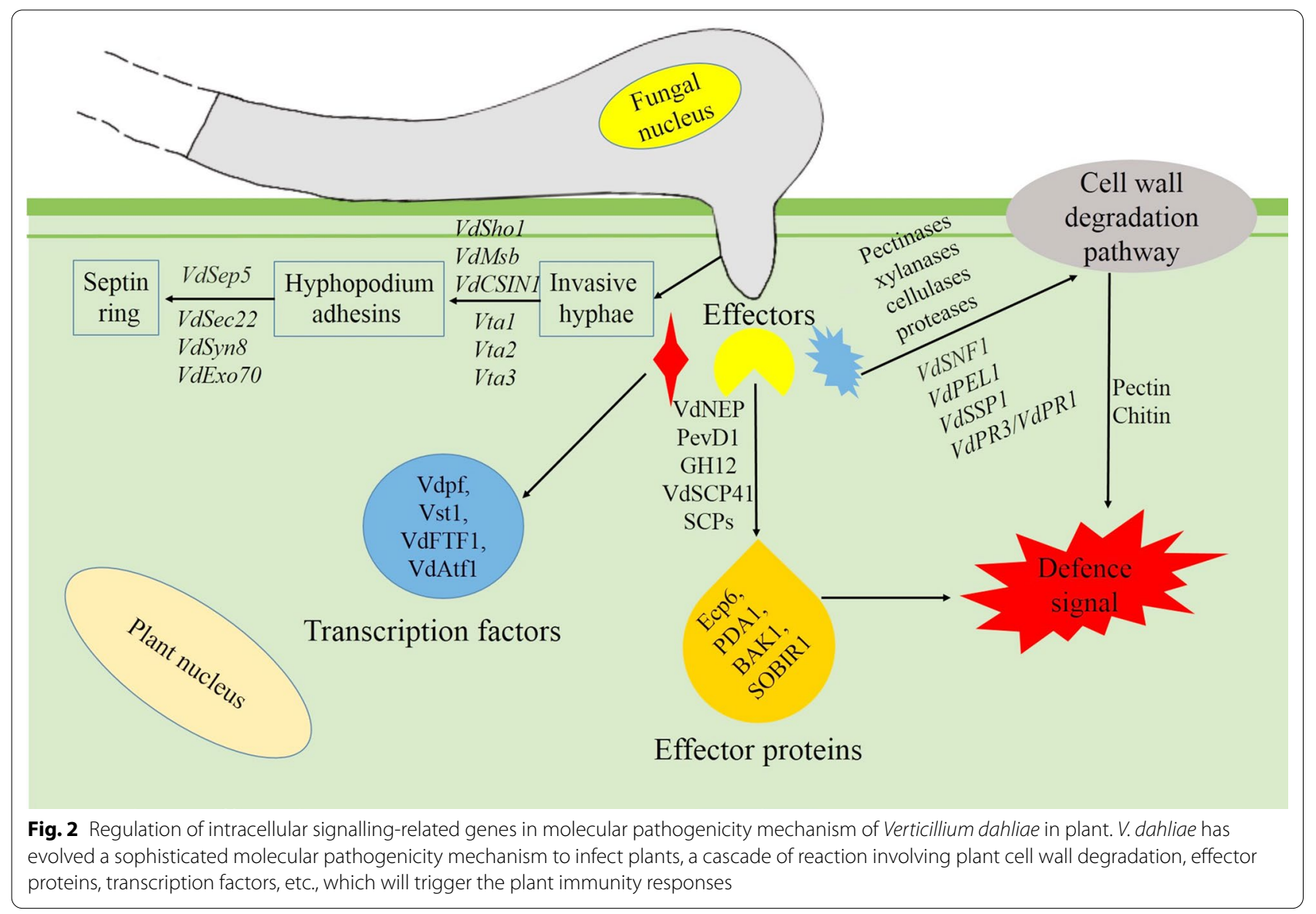

which were important in signaling/transcriptional regulation and iron/lipid metabolism (Klimes et al. 2015). Besides, LysM effector (VDAG_05180) located in an lineage-specific (LS) region contributed to virulence, which was highly up-regulated during infection (De Jonge et al. 2013). Chen et al. (2018) determined the genome of $V$. dahliae strain Vd991 and revealed that the Vd991 genome harbored several exclusive LS genes within LS regions (LSRs). Further phylogenetic analysis proved that G-LSR2 was acquired from $F$. oxysporum through HGT, whose targeted deletion mutants resulted in scarcity virulence to cotton, but did not affect virulence on lettuce and tomato. These results indicated that G-LSR2 significantly contributed to wilt pathogen infection to cotton and may represent an unique mechanism in the evolution of $V$. dahliae.

\section{Trans-kingdom RNA silencing}

RNA interference (RNAi)-based host-induced gene silencing (HIGS) is an effective strategy against pathogenic fungi by specific silencing of fungal virulence genes with miRNAs exported from the colonized host plants. Researchers have demonstrated cotton exported miRNAs to direct specific gene silencing ( $\mathrm{Clp}-1$ and $\mathrm{HiC}-15)$ in $V$. dahliae (Zhang et al. 2016b). V. dahilae also recruits sRNAs as effectors and transfers into Arabidopsis and cotton for silencing host genes, these evidences confirmed the bidirectional trans-kingdom RNAi and sRNA trafficking between pathogen and host plant (Jin and Guo 2018; Singh et al. 2010; Wang et al. 2016a, b). All these trans-kingdom transmitted molecular genetic materials contribute to the evolutionary arms race between pathogen and plant. Generally, RNAi transmission between pathogens and plant requires cell-to-cell and systemic movement of RNAi signals. As a broad host range pathogen, $V$. dahliae may have evolved to absorb and maintain RNAi signals from different hosts (Hua et al. 2018). Although the mechanism of RNA transmission is unclear, HIGS has been utilized to suppress Verticillium wilt disease by silencing virulence genes Ave1, Sge1 (six gene expression 1), NLP1, ALS (acetolactate synthase), $V d A K$ (adenylate kinase gene) and RGS (G protein signalling) of $V$. dahliae (Su et al. 2020; Wei et al. 2020; Xu et al. 2018). Thus, trans-kingdom sRNA transmission and RNA silencing mechanisms have been shown to be 
Table 1 Numerous genes directly/indirectly related to pathogenicity in V. dahliae

\begin{tabular}{|c|c|c|c|c|c|c|c|}
\hline \multirow[t]{2}{*}{ Gene } & \multirow[t]{2}{*}{ Annotation } & \multirow[t]{2}{*}{ Strain } & \multicolumn{3}{|c|}{ Growth characteristics } & \multirow[t]{2}{*}{ Pathogenicity } & \multirow[t]{2}{*}{ References } \\
\hline & & & Hypha growth & Sporulation & $\begin{array}{l}\text { Microsclerotial } \\
\text { formation }\end{array}$ & & \\
\hline 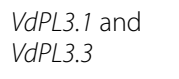 & $\begin{array}{l}\text { Pectin lyase } \\
\text { encoding protein }\end{array}$ & Vd991 & & & & + & Chen et al. (2016) \\
\hline VdSSP1 & $\begin{array}{l}\text { Specific secreted } \\
\text { protein }\end{array}$ & $\mathrm{VdG} 1$ & + & & & + & Liu et al. (2013) \\
\hline$V d P R 1$ & $\begin{array}{l}\text { Pathogenesis } \\
\text { related gene }\end{array}$ & Vd080 & + & + & + & + & Zhang et al. (2016c) \\
\hline$V d P R 3$ & $\begin{array}{l}\text { Pathogenesis } \\
\text { related gene }\end{array}$ & Vd080 & + & + & + & + & Zhang et al. (2015) \\
\hline VdFTF1 & $\begin{array}{l}\text { Transcription } \\
\text { factor contain- } \\
\text { ing fungal trans } \\
\text { domain }\end{array}$ & Vd991 & / & / & / & + & Zhang et al. (2018) \\
\hline$V d p f$ & $\begin{array}{l}\text { Transcription } \\
\text { factor }\end{array}$ & Vd991 & + & & + & + & Luo et al. (2016) \\
\hline VdSCP7 & $\begin{array}{l}\text { Specific secretory } \\
\text { protein }\end{array}$ & Vd592 & & & & - & Zhang et al. (2017a) \\
\hline VdASPF2 & Secretory factor & Vd991 & & - & + & + & Xie et al. (2017) \\
\hline VdGARP1 & $\begin{array}{l}\text { Glutamic acid-rich } \\
\text { protein }\end{array}$ & Vd592 & - & & + & + & Gao et al. (2010) \\
\hline$V d P K S 1$ & $\begin{array}{l}\text { Polyketide syn- } \\
\text { thase protein }\end{array}$ & Vd592 & & & + & + & Zhang et al. (2017b) \\
\hline VdNUC-2 & $\begin{array}{l}\text { Neurospora crassa } \\
\text { nuc- } 2 \text { homolog } \\
\text { protein }\end{array}$ & $\begin{array}{l}\text { Vd07DF2 and } \\
\text { VdBp2 }\end{array}$ & + & + & + & + & Deng et al. (2015) \\
\hline VdCYP1 & $\begin{array}{l}\text { Cytochrome P450 } \\
\text { monooxygenase } \\
\text { encoding protein }\end{array}$ & Vd991 & & & & + & Zhang et al. (2016a) \\
\hline Vdlscl & $\begin{array}{l}\text { sochorismatases } \\
\text { encoding protein }\end{array}$ & Vd991 & & & & + & Liu et al. (2014) \\
\hline VdNoxB/VdPIs 1 & $\begin{array}{l}\text { Hyphopodium } \\
\text { specific protein }\end{array}$ & Vd592 & - & & + & + & Zhao et al. (2016) \\
\hline $\operatorname{VdCYC8}$ & $\begin{array}{l}\text { Glucose repression } \\
\text { mediator protein }\end{array}$ & Vd080 & + & + & + & + & Li et al. (2015) \\
\hline VDH1 & $\begin{array}{l}\text { A class II hydro- } \\
\text { phobin }\end{array}$ & Dvd-T5 & / & & + & + & $\begin{array}{l}\text { Klimes et al. (2008) } \\
\text { and Klimes and } \\
\text { Dobinson (2006) }\end{array}$ \\
\hline$V d N L P$ & $\begin{array}{l}\text { NPP1 domain- } \\
\text { containing protein }\end{array}$ & Vd592 & & - & + & + & $\begin{array}{l}\text { Santhanam et al. } \\
\text { (2013) and Zhou } \\
\text { et al. (2012) }\end{array}$ \\
\hline ta2 & $\begin{array}{l}\text { Transcription } \\
\text { activator }\end{array}$ & $\begin{array}{l}\text { VdJR2, Vd52, Vd73 } \\
\text { and Va4 }\end{array}$ & + & + & - & + & Tran et al. (2014) \\
\hline$V d E g-1$ & Endoglucanase-1 & VdLs17 & + & & & + & $\begin{array}{l}\text { Maruthachalam } \\
\text { et al. (2011) }\end{array}$ \\
\hline VdSNF1 & $\begin{array}{l}\text { Sucrose non- } \\
\text { fermentingprotein } \\
\text { kinase }\end{array}$ & 70wt-r1 & & & + & + & Tzima et al. (2011) \\
\hline$C P C 1$ & $\begin{array}{l}\text { Regulator for } \\
\text { amino acid bio- } \\
\text { synthesis }\end{array}$ & VdJR2 & & & & + & Timpner et al. (2013) \\
\hline VdThi4 & $\begin{array}{l}\text { Thiamine biosyn- } \\
\text { thesis protein }\end{array}$ & $V d J R 2$ and $V \mid 43$ & + & & & + & $\begin{array}{l}\text { Hoppenau et al. } \\
\text { (2014) }\end{array}$ \\
\hline VdThit & $\begin{array}{l}\text { Thiamine trans- } \\
\text { porter protein }\end{array}$ & Vd991 & + & + & & + & Qi et al. (2016) \\
\hline VMK1 & MAP kinase & VdLs17 & & + & + & + & $\begin{array}{l}\text { Rauyaree et al. } \\
\text { (2005) }\end{array}$ \\
\hline
\end{tabular}


Table 1 (continued)

\begin{tabular}{|c|c|c|c|c|c|c|c|}
\hline \multirow[t]{2}{*}{ Gene } & \multirow[t]{2}{*}{ Annotation } & \multirow[t]{2}{*}{ Strain } & \multicolumn{3}{|c|}{ Growth characteristics } & \multirow[t]{2}{*}{ Pathogenicity } & \multirow[t]{2}{*}{ References } \\
\hline & & & Hypha growth & Sporulation & $\begin{array}{l}\text { Microsclerotial } \\
\text { formation }\end{array}$ & & \\
\hline VdPKACl & $\begin{array}{l}\text { The cAMP- } \\
\text { dependent } \\
\text { protein kinase A }\end{array}$ & 70wt-r1 & & + & - & + & Tzima et al. (2010) \\
\hline VdSgel & $\begin{array}{l}\text { Transcriptional } \\
\text { regulator }\end{array}$ & VdLs17 & + & + & & + & $\begin{array}{l}\text { Santhanam and } \\
\text { Thomma (2013) }\end{array}$ \\
\hline$V G B$ & $\begin{array}{l}\text { G protein } \beta \\
\text { subunit }\end{array}$ & 70wt-r1 & + & + & - & + & Tzima et al. (2012) \\
\hline VdShol & $\begin{array}{l}\text { Tetraspan trans- } \\
\text { membrane protein }\end{array}$ & Vd8 and $V d 991$ & & & + & + & Li et al. (2019a) \\
\hline Vayg1 & $\begin{array}{l}\text { Melanin biosyn- } \\
\text { thesis }\end{array}$ & JY & & & + & + & Fan et al. (2017) \\
\hline VdSsk1 & $\begin{array}{l}\text { Homolog to S. } \\
\text { cerevisiae Ssk1 }\end{array}$ & XS11 & + & & / & + & Zheng et al. (2019) \\
\hline VdHog 1 & $\begin{array}{l}\text { High-osmolarity } \\
\text { glycerol }\end{array}$ & XS11 & + & & + & + & $\begin{array}{l}\text { Wang et al. (2016a, } \\
\text { b) }\end{array}$ \\
\hline VdPbs2 & MAPK kinase & XS11 & & & + & + & Tian et al. (2016) \\
\hline Vta1, Vta2 and Vta3 & $\begin{array}{l}\text { transcription } \\
\text { activator of adhe- } \\
\text { sion } 1\end{array}$ & VdJR2 & & & + & + & Harting et al. (2020) \\
\hline Som 1 and Vta3 & $\begin{array}{l}\text { Nuclear transcrip- } \\
\text { tion factor }\end{array}$ & VdJR2 & - & - & + & + & Bui et al. (2019) \\
\hline$V d E G 1$ and $V d E G 3$ & $\begin{array}{l}\text { Glycoside hydro- } \\
\text { lase } 12 \text { protein }\end{array}$ & Vd991 & & & & + & Gui et al. (2017) \\
\hline$V d C P 1$ & $\begin{array}{l}\text { SnodProt1-like } \\
\text { protein }\end{array}$ & $\mathrm{XH}-8$ & / & / & & + & Zhang et al. (2017c) \\
\hline VdICSHI & $\begin{array}{l}\text { Isochorismatase } \\
\text { hydrolase }\end{array}$ & $\begin{array}{l}\text { Vd1396-9 and } \\
\text { Vs06-07 }\end{array}$ & / & / & / & + & Zhu et al. (2017) \\
\hline $\begin{array}{l}V d C m r 1 \text { and } \\
\text { VdPKS1 }\end{array}$ & $\begin{array}{l}\text { Transcription } \\
\text { factor }\end{array}$ & VdLs.17 & & & / & / & $\begin{array}{l}\text { Fang et al. (2019) } \\
\text { and Wang et al. } \\
\text { (2018c) }\end{array}$ \\
\hline $\mathrm{VdOCH} 1$ & $\begin{array}{l}\text { Initiation-specific } \\
\text { a-1, 6-mannosyl- } \\
\text { transferase }\end{array}$ & VdGn3 & + & + & + & + & Zhang et al. (2019a) \\
\hline VdMsn2 & $\begin{array}{l}\mathrm{C}_{2} \mathrm{H}_{2} \text { transcription } \\
\text { factor Msn2 }\end{array}$ & XS11 & + & & - & + & Tian et al. (2017) \\
\hline VdSkn7 & $\begin{array}{l}\text { Homolog to S. } \\
\text { cerevisiae Skn7 }\end{array}$ & XS11 & & + & + & + & Tang et al. (2017) \\
\hline Vst1 & $\begin{array}{l}\text { APSES family tran- } \\
\text { scription factor }\end{array}$ & DvdT5 and 383-2 & & + & + & / & $\begin{array}{l}\text { Sarmiento-Villamil } \\
\text { et al. (2018a) }\end{array}$ \\
\hline VdPEL 1 & Pectate lyase & Vd991 & & & & + & Yang et al. (2018) \\
\hline$V d P L P$ & $\begin{array}{l}\text { Patatin-like phos- } \\
\text { pholipase gene }\end{array}$ & Vd991 & + & + & - & + & Qi et al. (2018) \\
\hline $\begin{array}{l}\text { VdSec } 22 \text { and } \\
\text { VdSso } 1\end{array}$ & $\begin{array}{l}22 \text { soluble } \\
\mathrm{N} \text {-ethylmaleimide- } \\
\text { sensitive factor } \\
\text { attachment pro- } \\
\text { tein receptors }\end{array}$ & Vd991 & + & & & + & Wang et al. (2018a) \\
\hline $\begin{array}{l}\text { VdFKBP12 and } \\
\text { VdTOR }\end{array}$ & $\begin{array}{l}\text { Rapamycin bind- } \\
\text { ing protein, target } \\
\text { of rapamycin }\end{array}$ & Vd991 & & & & + & Li et al. (2019b) \\
\hline VdAtf1 & $\begin{array}{l}\text { bZIP transcription } \\
\text { factor }\end{array}$ & XS11 & & & & + & Tang et al. (2020) \\
\hline VdRGS1 & $\begin{array}{l}\text { Regulators of G } \\
\text { protein signalling }\end{array}$ & Vd8 and D-10-8F & & & + & + & $\begin{array}{l}\text { Sarmiento-Villamil } \\
\text { et al. (2020) and Xu } \\
\text { et al. (2018) }\end{array}$ \\
\hline
\end{tabular}


Table 1 (continued)

\begin{tabular}{|c|c|c|c|c|c|c|c|}
\hline \multirow[t]{2}{*}{ Gene } & \multirow[t]{2}{*}{ Annotation } & \multirow[t]{2}{*}{ Strain } & \multicolumn{3}{|c|}{ Growth characteristics } & \multirow[t]{2}{*}{ Pathogenicity } & \multirow[t]{2}{*}{ References } \\
\hline & & & Hypha growth & Sporulation & $\begin{array}{l}\text { Microsclerotial } \\
\text { formation }\end{array}$ & & \\
\hline$V d O G D H$ & $\begin{array}{l}\text { a-oxoglutarate } \\
\text { dehydrogenase }\end{array}$ & Vd991 & + & & + & + & Li et al. (2020) \\
\hline VdNPS & $\begin{array}{l}\text { Nonribosomal } \\
\text { peptide syn- } \\
\text { thetases }\end{array}$ & Vd991 & & & + & + & Luo et al. (2020) \\
\hline VdQase & $\begin{array}{l}\text { Cupin domain- } \\
\text { containing protein }\end{array}$ & $V d 9$ and $V d 21$ & & & & + & $\begin{array}{l}\text { El Hadrami et al. } \\
\text { (2015) }\end{array}$ \\
\hline $\begin{array}{l}\text { VdDpb4 and } \\
\text { Vdlsw2 }\end{array}$ & $\begin{array}{l}\text { Histone-fold pro- } \\
\text { tein, ATP-depend- } \\
\text { ent chromatin- } \\
\text { remodeling factor }\end{array}$ & V592 & + & & & + & Wang et al. (2020b) \\
\hline VdPDA1 & $\begin{array}{l}\text { Secretory polysac- } \\
\text { charide deacety- } \\
\text { lase }\end{array}$ & V592 & & & & + & Gao et al. (2019) \\
\hline VdTHI2O & $\begin{array}{l}\text { Thiamine biosyn- } \\
\text { thesis }\end{array}$ & Vd991 & + & + & & + & Qin et al. (2020) \\
\hline VdPIs1/VdNoxB & $\begin{array}{l}\text { Tetraspanin, } \\
\text { catalytic subunit of } \\
\text { membrane-bound } \\
\text { NADPH oxidases }\end{array}$ & V592 & & & & + & Zhao et al. (2016) \\
\hline$V d M c m 1$ & $\begin{array}{l}\text { MADS-box tran- } \\
\text { scription factor }\end{array}$ & XS11 & & + & + & + & Xiong et al. (2016) \\
\hline VdFreB & Ferric reductase & Vd991 & + & + & & + & Rehman et al. (2018) \\
\hline $\begin{array}{l}\text { VDAG_08640 and } \\
\text { VDAG_08676 }\end{array}$ & $\begin{array}{l}\text { bZIP transcription } \\
\text { factor }\end{array}$ & XS11 & & & / & + & Fang et al. (2017) \\
\hline STT3 & $\begin{array}{l}\text { Catalytic subunit } \\
\text { of the multi-subu- } \\
\text { nit oligosaccharyl } \\
\text { transferase }\end{array}$ & Vd991 & + & + & & + & Su et al. (2018) \\
\hline VDECH & Endochitinase & Vd080 & & & & + & Cheng et al. (2017) \\
\hline Vph1 and Vhb1 & $\begin{array}{l}\text { Transcription } \\
\text { factor }\end{array}$ & DvdT5 & / & - & & + & $\begin{array}{l}\text { Sarmiento-Villamil } \\
\text { et al. (2018b) }\end{array}$ \\
\hline VdRACK1 & $\begin{array}{l}\text { GB-like/RACK1 } \\
\text { protein }\end{array}$ & $\mathrm{Vd} 8$ & + & + & + & + & Yuan et al. (2017) \\
\hline VdACCd & ACC deaminase & 70V-WT & & - & + & + & $\begin{array}{l}\text { Tsolakidou et al. } \\
\text { (2019) }\end{array}$ \\
\hline VdMyo5 & $\begin{array}{l}\text { Member of the } \\
\text { Myosin } \vee \text { family }\end{array}$ & V592 & + & + & & + & Feng et al. (2018) \\
\hline VdILV2 and VdILV6 & $\begin{array}{l}\text { Acetolactate } \\
\text { synthase }\end{array}$ & Vd991 & & & & + & Wei et al. (2020) \\
\hline VdAK & $\begin{array}{l}\text { adenylate kinase } \\
\text { gene }\end{array}$ & Vd991 & & & & & Su et al. (2020) \\
\hline $\mathrm{Clp}-1$ and $\mathrm{HiC}-15$ & $\begin{array}{l}\mathrm{Ca}^{2+} \text {-dependent } \\
\text { cysteine protease } \\
\text { and isotricho- } \\
\text { dermin C-15 } \\
\text { hydroxylase }\end{array}$ & V592 & & & & + & Zhang et al. (2016b) \\
\hline VdSCPS & $\begin{array}{l}\text { Small cysteine-rich } \\
\text { proteins }\end{array}$ & Vd991 & & & & + & Wang et al. (2020a) \\
\hline VdCSIN1 & $\begin{array}{l}\text { Cellophane } \\
\text { surface-induced } \\
\text { gene }\end{array}$ & V592 & + & & & + & Sun et al. (2019) \\
\hline VdHapX & $\begin{array}{l}\text { bZip transcription } \\
\text { factor }\end{array}$ & XS11 & + & & + & + & Wang et al. (2018b) \\
\hline
\end{tabular}

\footnotetext{
"+" represents positive regulation, " -" represents negative regulation, "I" represents irrelevant, blank cell represents null value
} 
highly efficient in controlling the pathogens with broad host ranges.

\section{Conclusion}

In this paper, numerous genes directly/indirectly related to $V$. dahliae pathogenicity or virulence have been summarized, which covered microsclerotia development, pathogen infection, effector proteins, transcription factors, horizontal gene transfer, trans-kingdom RNA silencing, etc. (Fig. 2, Table 1), which illustrate the complexity of pathogenic mechanism of $V$. dahliae. Due to pathogens and plants have co-evolutionary relationship, therefore the pathogenic mechanism of pathogens and the mechanism of plants disease resistance, moreover, the variations between them, should be strengthened at the same time in order to achieve satisfactory results. As the ideal method to determine the particular genes' function in the living organism, Agrobacterium tumefaciens-mediated transformation acts an important role in constructing a library of T-DNA insertion mutants and analyzing the function of pathogenic genes in $V$. dahliae. The further application of new technologies such as hostinduced gene silencing and trans-kingdom RNA interference help to improve the disease resistance of plants. In addition, multi-omics integrative analysis and in-depth genome sequencing will provide a broader perspective in the discovery of regulatory pathogenic mechanism of the destructive plant pathogens. In this review, we have comprehensively analyzed many pathogenicity genes of $V$. dahliae in cotton, providing target gene resources for effective control of cotton Verticillium wilt, which will be contributed to understand the molecular mechanism of plant resistance to $V$. dahliae.

\section{Acknowledgements}

We apologize to colleagues whose work we do not cite here due to space limitations. We deeply appreciate the great support of all teachers and students in the research team throughout the research period.

\section{Authors' contributions}

Conceptualization: Feng $\mathrm{HJ}$ and Zhu HQ; Wrting-original draft: Zhang YL, Zhou $J$ and Zhao LH; Writing-review: Feng ZL, Wei F and Bai HY. All authors read and approved the final manuscript.

\section{Funding}

This work was supported by the Agricultural Science and Technology Innovation Program of Chinese Academy of Agricultural Sciences, and Central Publicinterest Scientific Institution Basal Research Fund (No. 1610162021031).

\section{Availability of data and materials}

Not applicable.

\section{Declarations}

Ethics approval and consent to participate

Not applicable.

\section{Consent for publication}

All data used for writing the manuscript has been cited with proper references.

\section{Competing interests}

The authors declare no competing interests.

\section{Author details}

${ }^{1}$ State Key Laboratory of Cotton Biology, Institute of Cotton Research of Chinese Academy of Agricultural Sciences, Anyang 455000, Henan, China. ${ }^{2}$ Western Agricultural Research Center of Chinese Academy of Agricultural Sciences, Changji 831100, Xinjiang, China. ${ }^{3}$ Engineering Research Centre of Cotton, Ministry of Education/College of Agriculture, Xinjiang Agricultural University, Urumqi 830052, Xinjiang, China.

Received: 12 May 2021 Accepted: 15 December 2021

Published online: 01 February 2022

\section{References}

Acharya B, Ingram TW, Oh Y, et al. Opportunities and challenges in studies of host-pathogen interactions and management of Verticillium dahliae in tomatoes. Plants. 2020;9(11):1622. https://doi.org/10.3390/plants9111 622.

Atallah ZK, Maruthachalam K, Toit L, et al. Population analyses of the vascular plant pathogen Verticillium dahliae detect recombination and transcontinental gene flow. Fungal Genet Biol. 2010;47(5):416-22. https://doi. org/10.1016/j.fgb.2010.02.003.

Bui TT, Harting R, Braus-Stromeyer SA, et al. Verticillium dahliae transcription factors Som 1 and Vta3 control microsclerotia formation and sequential steps of plant root penetration and colonisation to induce disease. New Phytol. 2019;221(4):2138-59. https://doi.org/10.1111/nph.15514.

Cai Q, Qiao LL, Wang M, et al. Plants send small RNAs in extracellular vesicles to fungal pathogen to silence virulence genes. Science. 2018;360(6393):1126-9. https://doi.org/10.1126/science.aar4142.

Chen JY, Xiao HL, Gui YJ, et al. Characterization of the Verticillium dahliae exoproteome involves in pathogenicity from cotton-containing medium. Front Microbiol. 2016;7:1709. https://doi.org/10.3389/fmicb.2016.01709.

Chen JY, Liu C, Gui YJ, et al. Comparative genomics reveals cotton-specific virulence factors in flexible genomic regions in Verticillium dahliae and evidence of horizontal gene transfer from Fusarium. New Phytol. 2018;217(2):756-70. https://doi.org/10.1111/nph.14861.

Cheng XX, Zhao LH, Klosterman SJ, et al. The endochitinase VDECH from Verticillium dahliae inhibits spore germination and activates plant defense responses. Plant Sci. 2017;259:12-23. https://doi.org/10. 1016/j.plantsci.2017.03.002.

Daboussi MJ, Capy P. Transposable elements in filamentous fungi. Annu Rev Microbiol. 2003;57:275-99.

De Jonge R, Van Esse HP, Kombrink A, et al. Conserved fungal LysM effector Ecp6 prevents chitin-triggered immunity in plants. Science. 2010;329(5994):953-5. https://doi.org/10.1126/science.1190791.

De Jonge R, Bolton MD, Kombrink A, et al. Extensive chromosomal reshuffling drives evolution of virulence in an asexual pathogen. Genome Res. 2013;23(8):1271-82. https://doi.org/10.1101/gr.152660.112.

De Sain M, Rep M. The role of pathogen-secreted proteins in fungal vascular wilt diseases. Int J Mol Sci. 2015;16(10):23970-93. https://doi.org/10. 3390/ijms161023970.

Deng S, Wang CY, Zhang $X$, et al. VdNUC-2, the key regulator of phosphate responsive signaling pathway, is required for Verticillium dahliae infection. PLoS ONE. 2015;10(12):e0145190. https://doi.org/10.1371/ journal.pone.0145190.

Depotter JRL, Shi-Kunne X, Missonnier H, et al. Dynamic virulence-related regions of the plant pathogenic fungus Verticillium dahliae display enhanced sequence conservation. Mol Ecol. 2019;28(15):3482-95. https://doi.org/10.1111/mec.15168.

Ding P, Redkar A. Pathogens suppress host transcription factors for rampant proliferation. Trends Plant Sci. 2018;23(11):950-3. https://doi.org/10. 1016/j.tplants.2018.08.010. 
Du X, Wang S, Gao F, et al. Expression of pathogenesis-related genes in cotton roots in response to Verticillium dahliae PAMP molecules. Sci China Life Sci. 2017;60(8):852-60.

El Hadrami A, Islam MR, Adam LR, et al. A cupin domain-containing protein with a quercetinase activity (VdQase) regulates Verticillium dahliae's pathogenicity and contributes to counteracting host defenses. Front Plant Sci. 2015;6:440. https://doi.org/10.3389/fpls.2015.00440.

Eynck C, Koopmann B, Grunewaldt-Stoecker G, et al. Differential interactions of Verticillium longisporum and $V$. dahliae with Brassica napus detected with molecular and histological techniques. Eur J Plant Pathol. 2007;118(3):259-74

Fan R, Klosterman SJ, Wang C, et al. Vayg1 is required for microsclerotium formation and melanin production in Verticillium dahliae. Fungal Genet Biol. 2017;98:1-11. https://doi.org/10.1016/j.fgb.2016.11.003.

Fang $Y$, Xiong D, Tian L, et al. Functional characterization of two bZIP transcription factors in Verticillium dahliae. Gene. 2017;626:386-94. https://doi. org/10.1016/j.gene.2017.05.061.

Fang Y, Klosterman SJ, Tian C, et al. Insights into VdCmr1-mediated protection against high temperature stress and UV irradiation in Verticillium dahliae. Environ Microbiol. 2019;21(8):2977-96. https://doi.org/10.1111/ 1462-2920.14695.

Feng Z, Tian J, Han L, et al. The Myosin5-mediated actomyosin motility system is required for Verticillium pathogenesis of cotton. Environ Microbiol. 2018;20(4):1607-21. https://doi.org/10.1111/1462-2920.14101.

Fradin EF, Thomma BP. Physiology and molecular aspects of Verticillium wilt diseases caused by V. dahliae and V. albo-atrum. Mol Plant Pathol. 2006;7(2):71-86. https://doi.org/10.1111/j.1364-3703.2006.00323.x.

Gao F, Zhou BJ, Li GY, et al. A glutamic acid-rich protein identified in Verticillium dahliae from an insertional mutagenesis affects microsclerotial formation and pathogenicity. PLoS ONE. 2010;5(12):e15319. https://doi.org/ 10.1371/journal.pone.0015319.

Gao F, Zhang BS, Zhao JH, et al. Deacetylation of chitin oligomers increases virulence in soil-borne fungal pathogens. Nat Plants. 2019;5(11):1167-76.

Gold SE, Paz Z, García-Pedrajas MD, et al. Rapid deletion production in fungi via Agrobacterium mediated transformation of OSCAR deletion constructs. J vis Exp. 2017;124:e55239. https://doi.org/10.3791/55239.

Gómez-Gómez L, Boller T. FLS2: an LRR receptor-like kinase involved in the perception of the bacterial elicitor flagellin in Arabidopsis. Mol Cell. 2000;5(6):1003-11. https://doi.org/10.1016/S1097-2765(00)80265-8.

Gui YJ, Chen JY, Zhang DD, et al. Verticillium dahliae manipulates plant immunity by glycoside hydrolase 12 proteins in conjunction with carbohydrate-binding module 1. Environ Microbiol. 2017;19(5):1914-32. https:// doi.org/10.1111/1462-2920.13695.

Harting R, Höfer A, Tran VT, et al. The Vta1 transcriptional regulator is required for microsclerotia melanization in Verticillium dahliae. Fungal Biol. 2020;124(5):490-500. https://doi.org/10.1016/j.funbio.2020.01.007.

Hoppenau CE, Trana VT, Kusch H, et al. Verticillium dahliae VdTHI4, involved in thiazole biosynthesis, stress response and DNA repair functions, is required for vascular disease induction in tomato. Environ Exp Bot. 2014;108(1):14-22. https://doi.org/10.1016/j.envexpbot.2013.12.015.

Hu D, Wang C, Tao F, et al. Whole genome wide expression profiles on germination of Verticillium dahliae microsclerotia. PLOS ONE. 2014;9(6):e100046. https://doi.org/10.1371/journal.pone.0100046.

Hua C, Zhao JH, Guo HS. Trans-kingdom RNA silencing in plant-fungal pathogen interactions. Mol Plant. 2018;11(2):235-44. https://doi.org/10. 1016/j.molp.2017.12.001.

Ingram TW, Oh Y, Adhikari TB, et al. Comparative genome analyses of 18 Verticillium dahliae tomato isolates reveals phylogenetic and race specific signatures. Front Microbiol. 2020;11: 573755. https://doi.org/10.3389/ fmicb.2020.573755.

Jin Y, Guo HS. Plant small RNAs responsive to fungal pathogen infection. In: Ma W, Wolpert T, editors. Plant pathogenic fungi and oomycetes. Methods in molecular biology, vol. 1848. New York, NY: Humana Press; 2018. p. 67-80. https://doi.org/10.1007/978-1-4939-8724-5_6.

Jin L, Chen D, Liao S, et al. Transcriptome analysis reveals downregulation of virulence-associated genes expression in a low virulence Verticillium dahliae strain. Arch Microbiol. 2019;201(7):927-41.

Jones JD, Dangl JL. The plant immune system. Nature. 2006;444(7117):323-9.

Klimes A, Dobinson KF. A hydrophobin gene, VDH1, is involved in microsclerotial development and spore viability in the plant pathogen Verticillium dahliae. Fungal Genet Biol. 2006;43(4):283-94. https://doi.org/10.1016/j. fgb.2005.12.006.

Klimes A, Amyotte SG, Grant S, et al. Microsclerotia development in Verticillium dahliae: regulation and differential expression of the hydrophobin gene VDH1. Fungal Genet Biol. 2008;45(12):1525-32. https://doi.org/10. 1016/j.fgb.2008.09.014.

Klimes A, Dobinson KF, Thomma BP, et al. Genomics spurs rapid advances in our understanding of the biology of vascular wilt pathogens in the genus Verticillium. Annu Rev Phytopathol. 2015;53:181-98. https://doi. org/10.1146/annurev-phyto-080614-120224.

Klosterman SJ, Atallah ZK, Vallad GE, et al. Diversity, pathogenicity, and management of Verticillium species. Annu Rev Phytopathol. 2009;47:39-62. https://doi.org/10.1146/annurev-phyto-080508-081748.

Klosterman SJ, Subbarao KV, Kang S, et al. Comparative genomics yields insights into niche adaptation of plant vascular wilt pathogens. PLoS Pathog. 2011;7(7):e1002137. https://doi.org/10.1371/journal.ppat.10021 37.

Li ZF, Liu YJ, Feng ZL, et al. VdCYC8, encoding CYC8 glucose repression mediator protein, is required for microsclerotia formation and full virulence in Verticillium dahliae. PLOS ONE. 2015;10(12): e0144020. https://doi.org/ 10.1371/journal.pone.0144020.

Li JJ, Zhou L, Yin CM, et al. The Verticillium dahliae Sho1-MAPK pathway regulates melanin biosynthesis and is required for cotton infection. Environ Microbiol. 2019a;21(12):4852-74. https://doi.org/10.1111/1462-2920. 14846.

Li L, Zhu T, Song Y, et al. Functional characterization of target of rapamycin signaling in Verticillium dahliae. Front Microbiol. 2019b;10:501. https:// doi.org/10.3389/fmicb.2019.00501.

Li XK, Su XF, Lu GQ, et al. VdOGDH is involved in energy metabolism and required for virulence of Verticillium dahliae. Curr Genet. 2020;66(2):345-59.

Liang Y, Cui S, Tang X, et al. An asparagine-rich protein Nbnrp1 modulate Verticillium dahliae protein PevD1-induced cell death and disease resistance in Nicotiana benthamiana. Front Plant Sci. 2018;9:303. https://doi.org/ 10.3389/fpls.2018.00303.

Liu SY, Chen JY, Wang JL, et al. Molecular characterization and functional analysis of a specific secreted protein from highly virulent defoliating Verticillium dahliae. Gene. 2013;529(2):307-16. https://doi.org/10.1016/j. gene.2013.06.089.

Liu T, Song T, Zhang X, et al. Unconventionally secreted effectors of two filamentous pathogens target plant salicylate biosynthesis. Nat Commun. 2014,5:4686.

Liu L, Xu L, Jia Q, et al. Arms race: diverse effector proteins with conserved motifs. Plant Signal Behav. 2019;14(2):1557008. https://doi.org/10.1080/ 15592324.2018 .1557008$.

Luo X, Xie C, Dong J, et al. Interactions between Verticillium dahliae and its host: vegetative growth, pathogenicity, plant immunity. Appl Microbiol Biotechnol. 2014;98(16):6921-32.

Luo X, Mao H, Wei Y, et al. The fungal-specific transcription factor Vdpf influences conidia production, melanized microsclerotia formation and pathogenicity in Verticillium dahliae. Mol Plant Pathol. 2016;17(9):136481. https://doi.org/10.1111/mpp.12367.

Luo X, Xie C, Dong J, et al. Comparative transcriptome analysis reveals regulatory networks and key genes of microsclerotia formation in the cotton vascular wilt pathogen. Fungal Genet Biol. 2019;126:25-36. https://doi. org/10.1016/j.fgb.2019.01.009.

Luo X, Tian T, Tan X, et al. VdNPS, a nonribosomal peptide synthetase, is involved in regulating virulence in Verticillium dahliae. Phytopathology. 2020;110(8):1398-409. https://doi.org/10.1094/PHYTO-02-20-0031-R.

Ma Z, Song T, Zhu L, et al. A phytophthora sojae glycoside hydrolase 12 protein is a major virulence factor during soybean infection and is recognized as a PAMP. Plant Cell. 2015;27(7):2057-72. https://doi.org/10.1105/tpc. 15.00390

Ma Z, Zhu L, Song T, et al. A paralogous decoy protects Phytophthora sojae apoplastic effector PsXEG1 from a host inhibitor. Science. 2017;355(6326):710-4. https://doi.org/10.1126/science.aai7919.

Maruthachalam K, Klosterman SJ, Kang S, et al. Identification of pathogenicityrelated genes in the vascular wilt fungus Verticillium dahliae by Agrobacterium tumefaciens-mediated T-DNA insertional mutagenesis. Mol Biotechnol. 2011;49(3):209-21. 
Mehrabi R, Bahkali AH, Abd-Elsalam KA, et al. Horizontal gene and chromosome transfer in plant pathogenic fungi affecting host range. FEMS Microbiol Rev. 2011;35(3):542-54. https://doi.org/10.1111/j.1574-6976. 2010.00263.x.

Qi X, Su X, Guo H, et al. A ku70 null mutant improves gene targeting frequency in the fungal pathogen Verticillium dahliae. World J Microbiol Biotechnol. 2015;31(12):1889-97.

Qi X, Su X, Guo H, et al. VdThit, a thiamine transport protein, is required for pathogenicity of the vascular pathogen Verticillium dahliae. Mol Plant Microbe Interact. 2016;29(7):545-59. https://doi.org/10.1094/ MPMI-03-16-0057-R.

Qi X, Li X, Guo H, et al. VdPLP, A patatin-like phospholipase in Verticillium dahliae, is involved in cell wall integrity and required for pathogenicity. Genes. 2018;9(3):162. https://doi.org/10.3390/genes9030162.

Qin T, Hao W, Sun R, et al. Verticillium dahliae VdTHI20, involved in pyrimidine biosynthesis, is required for DNA repair functions and pathogenicity. Int J Mol Sci. 2020;21(4):1378. https://doi.org/10.3390/ijms21041378.

Rauyaree P, Ospina-Giraldo MD, Kang S, et al. Mutations in VMK1, a mitogenactivated protein kinase gene, affect microsclerotia formation and pathogenicity in Verticillium dahliae. Curr Genet. 2005;48(2):109-16.

Rehman L, Su X, Guo H, et al. Protoplast transformation as a potential platform for exploring gene function in Verticillium dahliae. BMC Biotechnol. 2016;16(1):57.

Rehman L, Su X, Li X, et al. FreB is involved in the ferric metabolism and multiple pathogenicity-related traits of Verticillium dahliae. Curr Genet. 2018;64(3):645-59.

Santhanam P, Thomma BP. Verticillium dahliae Sgel differentially regulates expression of candidate effector genes. Mol Plant Microbe Interact. 2013;26(2):249-56. https://doi.org/10.1094/MPMI-08-12-0198-R.

Santhanam P, van Esse HP, Albert I, et al. Evidence for functional diversification within a fungal NEP1-like protein family. Mol Plant Microbe Interact. 2013;26(3):278-86. https://doi.org/10.1094/MPMI-09-12-0222-R.

Sarmiento-Villamil JL, García-Pedrajas NE, Baeza-Montañez L, et al. The APSES transcription factor Vst1 is a key regulator of development in microsclerotium- and resting mycelium-producing Verticillium species. Mol Plant Pathol. 2018a;19(1):59-76. https://doi.org/10.1111/mpp.12496.

Sarmiento-Villamil JL, Prieto P, Klosterman SJ, et al. Characterization of two homeodomain transcription factors with critical but distinct roles in virulence in the vascular pathogen Verticillium dahliae. Mol Plant Pathol. 2018b;19(4):986-1004. https://doi.org/10.1111/mpp.12584.

Sarmiento-Villamil JL, García-Pedrajas NE, Cañizares MC, et al. Molecular mechanisms controlling the disease cycle in the vascular pathogen Verticillium dahliae characterized through forward genetics and transcriptomics. Mol Plant Microbe Interact. 2020;33(6):825-41. https://doi. org/10.1094/MPMI-08-19-0228-R.

Shaban M, Miao Y, Ullah A, et al. Physiological and molecular mechanism of defense in cotton against Verticillium dahliae. Plant Physiol Biochem. 2018;125:193-204. https://doi.org/10.1016/j.plaphy.2018.02.011.

Shamră SN. Plant immune system: the basal immunity. Tsitol Genet. 2014;48(4):67-82.

Shi-Kunne X, van Kooten M, Depotter JRL, et al. The genome of the fungal pathogen Verticillium dahliae reveals extensive bacterial to fungal gene transfer. Genome Biol Evol. 2019;11(3):855-68. https://doi.org/10.1093/ gbe/evz040.

Singh S, Braus-Stromeyer SA, Timpner C, et al. Silencing of Vlaro2 for chorismate synthase revealed that the phytopathogen Verticillium longisporum induces the cross-pathway control in the xylem. Appl Microbiol Biotechnol. 2010;85(6):1961-76. https://doi.org/10.1007/ s00253-009-2269-0.

Song R, Li J, Xie C, et al. An overview of the molecular genetics of plant resistance to the Verticillium wilt pathogen Verticillium dahliae. Int J Mol Sci. 2020;21(3):1120. https://doi.org/10.3390/ijms21031120.

Stergiopoulos I, de Wit PJ. Fungal effector proteins. Annu Rev Phytopathol. 2009;47:233-63. https://doi.org/10.1146/annurev.phyto.112408.132637.

Su X, Rehman L, Guo H, et al. The oligosaccharyl transferase subunit STT3 mediates fungal development and is required for virulence in Verticillium dahliae. Curr Genet. 2018;64(1):235-46. https://doi.org/10.1007/ s00294-017-0729-0.

Su X, Lu G, Li X, et al. Host-induced gene silencing of an adenylate kinase gene involved in fungal energy metabolism improves plant resistance to
Verticillium dahliae. Biomolecules. 2020;10(1):127. https://doi.org/10. 3390/biom10010127.

Sun L, Qin J, Rong W, et al. Cellophane surface-induced gene, VdCSIN1, regulates hyphopodium formation and pathogenesis via CAMP-mediated signalling in Verticillium dahliae. Mol Plant Pathol. 2019;20(3):323-33. https://doi.org/10.1111/mpp.12756.

Tang C, Xiong D, Fang Y, et al. The two-component response regulator VdSkn7 plays key roles in microsclerotial development, stress resistance and virulence of Verticillium dahliae. Fungal Genet Biol. 2017;108:26-35. https://doi.org/10.1016/j.fgb.2017.09.002.

Tang C, Li T, Klosterman SJ, et al. The bZIP transcription factor VdAtf1 regulates virulence by mediating nitrogen metabolism in Verticillium dahliae. New Phytol. 2020;226(5):1461-79. https://doi.org/10.1111/nph.16481.

Tian L, Xu J, Zhou L, et al. VdMsb regulates virulence and microsclerotia production in the fungal plant pathogen Verticillium dahliae. Gene. 2014;550(2):238-44. https://doi.org/10.1016/j.gene.2014.08.035.

Tian L, Wang Y, Yu J, et al. The mitogen-activated protein kinase kinase VdPbs2 of Verticillium dahliae regulates microsclerotia formation, stress response, and plant infection. Front Microbiol. 2016;7:1532. https://doi. org/10.3389/fmicb.2016.01532.

Tian L, Yu J, Wang Y, et al. The $\mathrm{C}_{2} \mathrm{H}_{2}$ transcription factor VdMsn2 controls hyphal growth, microsclerotia formation, and virulence of Verticillium dahliae. Fungal Biol. 2017;121(12):1001-10. https://doi.org/10.1016/j.funbio. 2017.08.005.

Timpner C, Braus-Stromeyer SA, Tran VT, et al. The Cpc1 regulator of the cross-pathway control of amino acid biosynthesis is required for pathogenicity of the vascular pathogen Verticillium longisporum. Mol Plant Microbe Interact. 2013;26(11):1312-24. https://doi.org/10.1094/ MPMI-06-13-0181-R.

Tran VT, Braus-Stromeyer SA, Kusch H, et al. Verticillium transcription activator of adhesion Vta2 suppresses microsclerotia formation and is required for systemic infection of plant roots. New Phytol. 2014;202(2):565-81. https://doi.org/10.1111/nph.12671.

Tsolakidou MD, Pantelides LS, Tzima AK, et al. Disruption and overexpression of the gene encoding ACC (1-aminocyclopropane-1-carboxylic acid) deaminase in soil-borne fungal pathogen Verticillium dahliae revealed the role of ACC as a potential regulator of virulence and plant defense. Mol Plant Microbe Interact. 2019;32(6):639-53. https://doi.org/10.1094/ MPMI-07-18-0203-R.

Tzima A, Paplomatas EJ, Rauyaree P, et al. Roles of the catalytic subunit of CAMP-dependent protein kinase $A$ in virulence and development of the soilborne plant pathogen Verticillium dahliae. Fungal Genet Biol. 2010;47(5):406-15. https://doi.org/10.1016/j.fgb.2010.01.007.

Tzima AK, Paplomatas EJ, Rauyaree P, et al. VdSNF1, the sucrose nonfermenting protein kinase gene of Verticillium dahliae, is required for virulence and expression of genes involved in cell-wall degradation. Mol Plant Microbe Interact. 2011;24(1):129-42. https://doi.org/10.1094/ MPMI-09-09-0217.

Tzima AK, Paplomatas EJ, Tsitsigiannis DI, et al. The G protein $\beta$ subunit controls virulence and multiple growth- and development-related traits in Verticillium dahliae. Fungal Genet Biol. 2012;49(4):271-83. https://doi.org/10. 1016/j.fgb.2012.02.005.

Wang JY, Cai Y, Gou JY, et al. VdNEP, an elicitor from Verticillium dahliae, induces cotton plant wilting. Appl Environ Microbiol. 2004;70(8):4989-95. https://doi.org/10.1128/AEM.70.8.4989-4995.2004.

Wang B, Yang $X$, Zeng $H$, et al. The purification and characterization of a novel hypersensitive-like response-inducing elicitor from Verticillium dahliae that induces resistance responses in tobacco. Appl Microbiol Biotechnol. 2012;93(1):191-201. https://doi.org/10.1007/s00253-011-3405-1.

Wang M, Weiberg A, Lin FM, et al. Bidirectional cross-kingdom RNAi and fungal uptake of external RNAs confer plant protection. Nat Plants. 2016a;2(10):1-10. https://doi.org/10.1038/nplants.2016.151.

Wang Y, Tian L, Xiong D, et al. The mitogen-activated protein kinase gene, $V d H o g$ 1, regulates osmotic stress response, microsclerotia formation and virulence in Verticillium dahliae. Fungal Genet Biol. 2016b;88:13-23. https://doi.org/10.1016/j.fgb.2016.01.011.

Wang J, Tian L, Zhang DD, et al. SNARE-encoding genes VdSec22 and VdSso 1 mediate protein secretion required for full virulence in Verticillium dahliae. Mol Plant Microbe Interact. 2018a;31(6):651-64. https://doi.org/ 10.1094/MPMI-12-17-0289-R. 
Wang Y, Deng C, Tian L, et al. The transcription factor VdHapX controls iron homeostasis and is crucial for virulence in the vascular pathogen Verticillium dahliae. mSphere. 2018b;3(5):e00400-18. https://doi.org/10. 1128/mSphere.00400-18.

Wang Y, Hu X, Fang Y, et al. Transcription factor $V d C m r 1$ is required for pigment production, protection from UV irradiation, and regulates expression of melanin biosynthetic genes in Verticillium dahliae. Microbiology. 2018c;164(4):685-96. https://doi.org/10.1099/mic.0.000633.

Wang D, Tian L, Zhang DD, et al. Functional analyses of small secreted cysteine-rich proteins identified candidate effectors in Verticillium dahliae. Mol Plant Pathol. 2020a;21(5):667-85. https://doi.org/10.1111/ mpp.12921.

Wang S, Wu XM, Liu CH, et al. Verticillium dahliae chromatin remodeling facilitates the DNA damage repair in response to plant ROS stress. PLoS Pathog. 2020b;16(4): e1008481. https://doi.org/10.1371/journal.ppat. 1008481.

Wei C, Qin T, Li Y, et al. Host-induced gene silencing of the acetolactate synthases VdILV2 and VdILV6 confers resistance to Verticillium wilt in cotton (Gossypium hirsutum L.). Biochem Biophys Res Commun. 2020;524(2):392-7. https://doi.org/10.1016/j.bbrc.2020.01.126.

Wu L, Du G, Bao R, et al. De novo assembly and discovery of genes involved in the response of Solanum sisymbriifolium to Verticillium dahliae. Physiol Mol Biol Plants. 2019;25(4):1009-27. https://doi.org/10.1007/ s12298-019-00666-4.

Xie C, Li Q, Yang X. Characterization of VdASP F2 secretory factor from Verticillium dahliae by a fast and easy gene knockout system. Mol Plant Microbe Interact. 2017;30(6):444-54. https://doi.org/10.1094/ MPMI-01-17-0007-R.

Xiong D, Wang Y, Tian C. Transcriptomic profiles of the smoke tree wilt fungus Verticillium dahliae under nutrient starvation stresses. Mol Genet Genomics. 2015;290(5):1963-77. https://doi.org/10.1007/ s00438-015-1052-4.

Xiong D, Wang Y, Tian L, et al. MADS-Box transcription factor VdMcm 1 regulates conidiation, microsclerotia formation, pathogenicity, and secondary metabolism of Verticillium dahliae. Front Microbiol. 2016;7:1192. https:// doi.org/10.3389/fmicb.2016.01192.

$\mathrm{Xu}$ J, Wang $X$, Li Y, et al. Host-induced gene silencing of a regulator of $G$ protein signalling gene (VdRGS1) confers resistance to Verticillium wilt in cotton. Plant Biotechnol J. 2018;16(9):1629-43. https://doi.org/10.1111/ pbi.12900.

Yang Y, Zhang Y, Li B, et al. A Verticillium dahliae pectate lyase induces plant immune responses and contributes to virulence. Front Plant Sci. 2018;9:1271. https://doi.org/10.3389/fpls.2018.01271.

Yuan L, Su Y, Zhou S, et al. A RACK1-like protein regulates hyphal morphogenesis, root entry and in vivo virulence in Verticillium dahliae. Fungal Genet Biol. 2017;99:52-61. https://doi.org/10.1016/j.fgb.2017.01.003.

Zhang Y, Wang X, Yang S, et al. Cloning and characterization of a Verticillium wilt resistance gene from Gossypium barbadense and functional analysis in Arabidopsis thaliana. Plant Cell Rep. 2011;30(11):2085-96. https://doi. org/10.1007/s00299-011-1115-x.

Zhang YL, Li ZF, Feng ZL, et al. Isolation and functional analysis of the pathogenicity-related gene VdPR3 from Verticillium dahliae on cotton. Curr Genet. 2015;61(4):555-66. https://doi.org/10.1007/s00294-015-0476-z.

Zhang DD, Wang XY, Chen JY, et al. Identification and characterization of a pathogenicity-related gene VdCYP1 from Verticillium dahliae. Sci Rep. 2016a;6:27979. https://doi.org/10.1038/srep27979.

Zhang T, Zhao YL, Zhao JH, et al. Cotton plants export microRNAs to inhibit virulence gene expression in a fungal pathogen. Nat Plants. 2016b;2(10):16153. https://doi.org/10.1038/nplants.2016.153.

Zhang YL, Li ZF, Feng ZL, et al. Functional analysis of the pathogenicity-related gene VdPR1 in the vascular wilt fungus Verticillium dahliae. PLOS ONE. 2016c;11(11): e0166000. https://doi.org/10.1371/journal.pone.0166000.

Zhang L, Ni H, Du X, et al. The Verticillium-specific protein VdSCP7 localizes to the plant nucleus and modulates immunity to fungal infections. New Phytol. 2017a;215(1):368-81. https://doi.org/10.1111/nph.14537.

Zhang T, Zhang B, Hua C, et al. VdPKS1 is required for melanin formation and virulence in a cotton wilt pathogen Verticillium dahliae. Sci China Life Sci. 2017b;60(8):868-79. https://doi.org/10.1007/s11427-017-9075-3.

Zhang Y, Gao Y, Liang Y, et al. The Verticillium dahliae SnodProt1-like protein $V d C P 1$ contributes to virulence and triggers the plant immune system. Front Plant Sci. 2017c;8:1880. https://doi.org/10.3389/fpls.2017.01880.
Zhang WQ, Gui YJ, Short DPG, et al. Verticillium dahliae transcription factor VdFTF1 regulates the expression of multiple secreted virulence factors and is required for full virulence in cotton. Mol Plant Pathol. 2018;19(4):841-57. https://doi.org/10.1111/mpp.12569.

Zhang J, Zhang Y, Yang J, et al. The a-1,6-mannosyltransferase $\mathrm{VdOCH}$ plays a major role in microsclerotium formation and virulence in the soil-borne pathogen Verticillium dahliae. Fungal Biol. 2019a;123(7):539-46. https:// doi.org/10.1016/j.funbio.2019.05.007.

Zhang Y, Gao Y, Liang Y, et al. Verticillium dahliae PevD1, an Alt a 1-like protein, targets cotton PR5-like protein and promotes fungal infection. J Exp Bot. 2019b;70(2):613-26. https://doi.org/10.1093/jxb/ery351.

Zhang YL, Zhao LH, Feng ZL, et al. The role of a new compound micronutrient multifunctional fertilizer against Verticillium dahliae on cotton. Pathogens. 2021;10(1):81. https://doi.org/10.3390/pathogens10010081.

Zhao YL, Zhou TT, Guo HS. Hyphopodium-specific VdNoxB/VdPIs 1-dependent ROS- $\mathrm{Ca}^{2+}$ signaling is required for plant infection by Verticillium dahliae. PLoS Pathog. 2016;12(7): e1005793. https://doi.org/10.1371/journal. ppat.1005793.

Zheng J, Tang C, Deng C, et al. Involvement of a response regulator VdSsk1 in stress response, melanin biosynthesis and full virulence in Verticillium dahliae. Front Microbiol. 2019;10:606. https://doi.org/10.3389/fmicb. 2019.00606.

Zhou BJ, Jia PS, Gao F, et al. Molecular characterization and functional analysis of a necrosis- and ethylene-inducing, protein-encoding gene family from Verticillium dahliae. Mol Plant Microbe Interact. 2012;25(7):964-75. https://doi.org/10.1094/MPMl-12-11-0319.

Zhou R, Zhu T, Han L, et al. The asparagine-rich protein NRP interacts with the Verticillium effector PevD1 and regulates the subcellular localization of cryptochrome 2. J Exp Bot. 2017a;68(13):3427-40. https://doi.org/10. 1093/jxb/erx192.

Zhou TT, Zhao YL, Guo HS. Secretory proteins are delivered to the septinorganized penetration interface during root infection by Verticillium dahliae. PLoS Pathog. 2017b;13(3):e1006275. https://doi.org/10.1371/ journal.ppat.1006275.

Zhou JL, Feng ZL, Liu SC, et al. CGTase, a novel antimicrobial protein from Bacillus cereus YUPP-10, suppresses Verticillium dahliae and mediates plant defence responses. Mol Plant Pathol. 2021;22(1):130-44. https://doi.org/ $10.1111 / \mathrm{mpp} .13014$.

Zhu X, Soliman A, Islam MR, et al. Verticillium dahliae's isochorismatase hydrolase is a virulence factor that contributes to interference with potato's salicylate and jasmonate defense signaling. Front Plant Sci. 2017;8:399. https://doi.org/10.3389/fpls.2017.00399.

Ready to submit your research? Choose BMC and benefit from:

- fast, convenient online submission

- thorough peer review by experienced researchers in your field

- rapid publication on acceptance

- support for research data, including large and complex data types

- gold Open Access which fosters wider collaboration and increased citations

- maximum visibility for your research: over 100M website views per year

At BMC, research is always in progress.

Learn more biomedcentral.com/submissions 